This item is the archived peer-reviewed author-version of:

\title{
Synthetic phenolic antioxidants and their metabolites in indoor dust from homes and microenvironments
}

\section{Reference:}

Wang Wei, Asimakopoulos Alexandros G., Abualnaja Khalid O., Covaci Adrian, Govindan Malarvannan, et al..- Synthetic phenolic antioxidants and their metabolites in indoor dust from homes and microenvironments

Environmental science and technology / American Chemical Society - ISSN 0013-936X - 50:1(2016), p. 428-434

Full text (Publishers DOI): http://dx.doi.org/doi:10.1021/ACS.EST.5B04826

To cite this reference: http://hdl.handle.net/10067/1311320151162165141 


\section{Article}

\section{Synthetic phenolic antioxidants and their metabolites in indoor dust from homes and microenvironments}

Wei Wang, ALEXANDROS GEORGE ASIMAKOPOULOS, Khalid Abualnaja, Adrian Covaci, Bondi Gevao, Boris Johnson-Restrepo, Taha Kumosani, Govindan Malarvannan, Tu Binh

Minh, Hyo-Bang Moon, Haruhiko Nakata, Ravindra K Sinha, and Kurunthachalam Kannan

Environ. Sci. Technol., Just Accepted Manuscript • DOI: 10.1021/acs.est.5b04826 • Publication Date (Web): 02 Dec 2015

Downloaded from http://pubs.acs.org on December 6, 2015

\section{Just Accepted}

"Just Accepted" manuscripts have been peer-reviewed and accepted for publication. They are posted online prior to technical editing, formatting for publication and author proofing. The American Chemical Society provides "Just Accepted" as a free service to the research community to expedite the dissemination of scientific material as soon as possible after acceptance. "Just Accepted" manuscripts appear in full in PDF format accompanied by an HTML abstract. "Just Accepted" manuscripts have been fully peer reviewed, but should not be considered the official version of record. They are accessible to all readers and citable by the Digital Object Identifier (DOI@). "Just Accepted" is an optional service offered to authors. Therefore, the "Just Accepted" Web site may not include all articles that will be published in the journal. After a manuscript is technically edited and formatted, it will be removed from the "Just Accepted" Web site and published as an ASAP article. Note that technical editing may introduce minor changes to the manuscript text and/or graphics which could affect content, and all legal disclaimers and ethical guidelines that apply to the journal pertain. ACS cannot be held responsible for errors or consequences arising from the use of information contained in these "Just Accepted" manuscripts. 
1 Synthetic phenolic antioxidants and their metabolites in indoor dust from

2 homes and microenvironments

4 Wei Wang', Alexandros G. Asimakopoulos', Khalid O. Abualnaja ${ }^{1}$, Adrian Covaci ${ }^{3}$, 5 Bondi Gevao ${ }^{4}$, Boris Johnson-Restrepo ${ }^{5}$, Taha A. Kumosani ${ }^{2}$, Govindan 6 Malarvannan ${ }^{3}$, Tu Binh Minh ${ }^{6}$, Hyo-Bang Moon ${ }^{7}$, Haruhiko Nakata ${ }^{8}$, Ravindra K. 7 Sinha ${ }^{9}$, and Kurunthachalam Kannan ${ }^{1,2, *}$

$9{ }^{1}$ Wadsworth Center, New York State Department of Health, and Department of 10 Environmental Health Sciences, School of Public Health, State University of New York at 11 Albany, Empire State Plaza, P.O. Box 509, Albany, New York 12201-0509, United States

${ }^{2}$ Biochemistry Department, Faculty of Science, Experimental Biochemistry Unit, King Fahd 14 Medical Research Center and Bioactive Natural Products Research Group, King Abdulaziz 15 University, Jeddah, Saudi Arabia

$16{ }^{3}$ Toxicological Center, University of Antwerp, Universiteitsplein 1, 2610 Wilrijk-Antwerp, 17 Belgium

${ }^{4}$ Environmental Management Program, Environment and Life Sciences Center, Kuwait

${ }^{6}$ Faculty of Chemistry, Hanoi University of Science, Vietnam National University, Hanoi, 19 Le Thanh Tong, Hoan Kiem, Hanoi, Vietnam

$27{ }^{7}$ Department of Marine Sciences and Convergent Technology, College of Science and 28 Technology, Hanyang University, Ansan, South Korea 
$30{ }^{8}$ Graduate School of Science and Technology, Kumamoto University, 2-39-1 Kurokami,

31 Kumamoto 860-8555, Japan

32

33

${ }^{9}$ Department of Zoology, Patna University, Patna, 800 005, India

34

35

* Corresponding author at: Wadsworth Center, Empire State Plaza, P.O. Box 509,

36 Albany, NY 12201-0509, USA. Tel.: +1 518474 0015, fax: +1 518-473- 2895, E-mail

37 address: Kurunthachalam.kannan@health.ny.gov (K. Kannan).

38

39

Submitted to : ES\&T

40

\section{TOC}

42

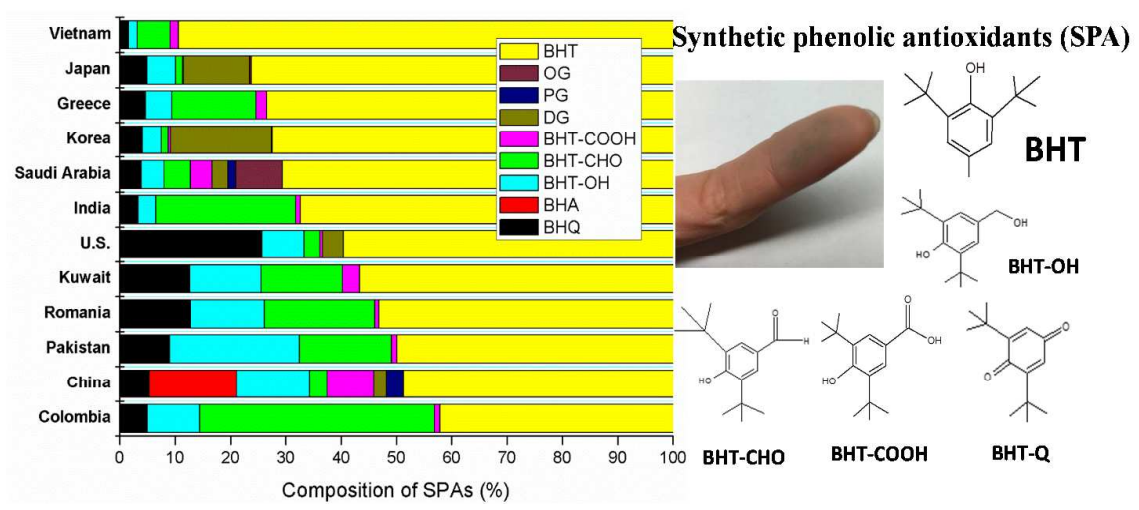


44 Abstract

45 Synthetic phenolic antioxidants (SPAs), including 2,6-di-tert-butyl-4-hydroxytoluene 46 (BHT), are extensively used in food, cosmetic and plastic industries. Nevertheless, limited 47 information is available on human exposures, other than the dietary sources, to SPAs. In this study, occurrence of nine SPAs and their metabolites/degradation products was determined in 339 indoor dust collected from 12 countries. BHT was found in $99.5 \%$ of

50 indoor dust samples from homes and microenvironments at concentrations that ranged from $51<$ LOQ to $118 \mu \mathrm{g} / \mathrm{g}$ and 0.10 to $3460 \mu \mathrm{g} / \mathrm{g}$, respectively. This is the first study to measure 52 BHT metabolites in house dust $(0.01-35.1 \mu \mathrm{g} / \mathrm{g})$ and their concentrations accounted for $9.2 \%$ 53 to $58 \%$ of the sum concentrations ( $\mathrm{SPA}$ ). 3,5-di-tert-butyl-4-hydroxybenzaldehyde (BHT-

54

\section{CHO), 2,6-di-tert-butyl-4-(hydroxymethyl)phenol (BHT-OH), 2,6-di-tert-butyl-1,4-} benzoquinone (BHT-Q) were the major derivatives of BHT found in dust samples. The concentrations of gallic acid esters (gallates) in dust from homes and microenvironments ranged from $<$ LOQ to 18.2 and $<$ LOQ to $684 \mu \mathrm{g} / \mathrm{g}$, respectively. The concentrations and profiles of SPAs varied among countries and microenvironments. Significantly elevated concentrations of SPAs were found in dust from an e-waste workshop $(1530 \mu \mathrm{g} / \mathrm{g})$. The estimated daily intake (EDI) of BHT via house dust ingestion ranged from 0.40 to 222 $\mathrm{ng} / \mathrm{kg} / \mathrm{d}\left(95^{\text {th }}\right.$ percentile). 
Introduction

65 Synthetic phenolic antioxidants (SPAs) are the most frequently used antioxidants in many 66 consumer products including foodstuffs. ${ }^{1}$ The U.S. Food and Drug Administration (FDA)

67 and the European Union (EU) regulate the use of SPAs, including 2,6-di-tert-butyl-4-

68 hydroxytoluene (BHT), 2-tert-butyl-4-methoxyphenol (BHA), propyl (PG)-, octyl- (OG) and

69 dodecyl- (DG) gallate as food additives. ${ }^{2,3}$ SPAs are widely used in food and feed industries

70 including confectionery and edible oil industry. BHT is also used in a wide range of

71 cosmetics. ${ }^{4}$. Furthermore, SPAs are currently used in a wide range of products including

72 packing materials, rubber, plastics, hand-washing soap, pet foods, chewing gum and as anti-

73 skinning agents in paints and inks ${ }^{1}$. SPAs might be released into the indoor environment

74 from various household commodities and indoor dust can be a source of human exposure.

75 In recent years, concerns with regard to the safety of SPAs have increased, due to

76 their potential toxicity. ${ }^{4}$ Nevertheless, considerable controversy surrounds with regard to the

77 link between BHT/BHA and carcinogenicity. ${ }^{5,6}$ BHA has been shown to possess estrogenic

78 properties in breast cancer cells, and has been shown to disrupt estrogen receptor

79 functions. ${ }^{4,6}$ A few other studies have not found such estrogenic effects. ${ }^{7,8}$ The metabolites of

80 BHT have been reported to induce peroxides in mice and rats, which results in cellular DNA

81 damage and instigate cancer. ${ }^{9}$ BHT has been reported to be metabolized to 3,5-di-tertbutyl-4- 
82 hydroxybenzoic acid (BHT-COOH) through oxidation of alkyl group via the corresponding alcohol (BHT-OH) and aldehyde (BHT-CHO) or to 2,6-di-tert-butylcyclohexa-2,5-diene-1,4dione (BHT-Q) through oxidation of the $\pi$-system. ${ }^{10}$ In addition, BHT-OH and BHT-CHO are photoproducts of BHT. ${ }^{11}$

Although SPAs are considered safe for human health at recommended doses (for instance, the acceptable daily intake of BHT has been set at $250 \mu \mathrm{g} / \mathrm{kg} /$ day), its ubiquitous presence and the controversial toxicological data suggest the need for more information on these classes of chemicals. A few studies have reported the occurrence of SPAs in surface water, wastewater and foodstuffs. ${ }^{4,12,13,14,15}$ However, no information is available on the occurrence of SPAs and their metabolites in indoor environments. Because SPAs are used in a variety of consumer products, including adhesives, personal care products and pharmaceuticals ${ }^{1}$, humans can be exposed to these compounds via both oral ingestion and inhalation of settled dust. ${ }^{16,17}$ In this study, a wide range of SPAs and their metabolites were determined in indoor dust samples collected from 12 countries, for the first time, to elucidate the occurrence, sources and human exposure profiles through dust ingestion.

\section{Materials and Methods}

Sample Collection. A total of 339 indoor dust samples were collected from 12 countries, with 241 samples from homes and 98 from other microenvironments (laboratories, offices, 
101 cars, and e-waste workshop) (Table S1; Supporting Information). House dust samples (5-50

102 g) were collected from select cities in China (CN, number of samples: $n=26)$, U.S. (US,

103 14), India (IN, 30), Japan (JP, 10), Greece (GR, 20), Colombia (CO, 40), Pakistan (PK, 22),

104 Saudi Arabia (SA, 10), South Korea (KR, 26), Kuwait (KW, 15), Romania (RO, 20), and

105 Vietnam (VN, 8) during 2012 to 2014. Dust samples from laboratories, offices, cars, and

106 public areas were collected from South Korea (lab, $n=10$; office, 14), Kuwait (car, 15),

107 Pakistan (car, 6; office 31), Saudi Arabia (car, 10), and Vietnam (e-waste work shop, 4;

108 market, 8). Floor dust samples were obtained from vacuum cleaner bags in each of the

109 sampling sites following the same sampling protocol, with the exception of samples from

110 China and India, which were obtained by sweeping the floor. The vacuum and the sweeping

111 tool were pre-cleaned before each sampling. Only bedrooms and living rooms of homes and

112 apartments (all countries) were selected for sampling. We employed volunteers to collect

113 samples in each country, and these volunteers sampled sites for which they had access. This

114 approach of opportunistic sampling is not expected to be fully representative of the country,

115 but it can obtain a sufficient sample size in the variety of different types of

116 microenvironments (homes, offices, cars, etc.) desired to meet the objectives of the study.

117 All samples were transported to the laboratory at Wadsworth Center, sieved through a 150

$118 \mu \mathrm{m}$ sieve, homogenized, packed in clean aluminum foil, and stored at $4{ }^{\circ} \mathrm{C}$ until analysis. 
Chemicals and Reagents. Target analytes and their structure are shown in Table S2. methanol was supplied by J.T. Baker (Phillipsburg, NJ). Ultra-pure water (18.2 $\Omega$ ) was generated using a Milli-Q system (Millipore, Billerica, MA). $\mathrm{mL}$ glass tube. After spiking with BHT-d21, ${ }^{13} \mathrm{C}_{12}-\mathrm{MeP}$ and ${ }^{13} \mathrm{C}_{12}-\mathrm{PrP}$ (as internal standards, IS), sample was extracted with a $5 \mathrm{~mL}$ solvent mixture of dichloromethane/hexane $(3: 1, \mathrm{v} / \mathrm{v})$

130 by shaking for $60 \mathrm{~min}$. The mixture was centrifuged at $2000 \mathrm{x} \mathrm{g}$ for $10 \mathrm{~min}$ (Eppendorf 131 Centrifuge 5804, Hamburg, Germany), and the supernatant was transferred into a glass tube.

132 The extraction repeated twice with the same amount of solvent, and the extracts were 133 combined, concentrated and solvent exchanged to $300 \mu \mathrm{L}$ ethyl acetate. Prior to analysis by 134 high performance liquid chromatography-tandem mass spectrometry (HPLC-MS/MS), $50 \mu \mathrm{L}$ 135 of the extract was diluted to $250 \mu \mathrm{L}$ with methanol in HPLC vials and the remaining $250 \mu \mathrm{L}$ 136 of the extract was analyzed on a gas chromatograph-mass spectrometer (GC-MS).

137 Instrumental Analysis. BHT was analyzed using a GC (Agilent Technologies 6890) 
138

141

142

143 analyzed, a procedural blank, a pair of pre-extraction matrix spike sample (fortified before

151 extraction), a pair of matrix match (fortified after extraction) and duplicate samples were 152

153 found in procedural blanks in one batch, and background subtraction was performed for this

154 batch of samples. Recoveries of SPAs in spiked dust matrices ranged from $69 \pm 22 \%$ for OG

155 to $106 \pm 12 \%$ for BHT (Table S4). Duplicate analysis of randomly selected samples $(\mathrm{n}=12)$

156 showed a coefficient of variation of $<20 \%$. Quantification of SPAs was performed by an 
157 isotope-dilution method based on the response of BHT-d21 (for BHT), ${ }^{13} \mathrm{C}_{12}$-MeP (for BHT-

158 Q, BHA, BHT-OH, BHT-CHO, and BHT-COOH), ${ }^{13} \mathrm{C}_{12}-\mathrm{PrP}$ (for OG, PG and DG). The

159 limits of quantification (LOQs) were $0.12 \mathrm{ng} / \mathrm{g}$ for BHT-CHO and BHT-COOH, $0.6 \mathrm{ng} / \mathrm{g}$ for

160 BHA, $1.2 \mathrm{ng} / \mathrm{g}$ for BHT, BHT-Q and BHT-OH, and $2.4 \mathrm{ng} / \mathrm{g}$ for DG, OG and PG (Table S4),

161 which were calculated from the lowest acceptable calibration standard and a nominal sample

162 weight of $0.25 \mathrm{~g}$ (LOQs for LC/MS/MS analyses were corrected based on diluted

163 subsamples). A midpoint calibration standard (in methanol) was injected as a check for

164 instrumental drift in sensitivity after every 20 samples, and a pure solvent (methanol) was

165 injected as a check for sample carry-over. Instrumental calibration was verified by injection

166 of 10 calibration standards (ranging from 0.02 to $100 \mathrm{ng} / \mathrm{g}$ ), and the linearity of the

167 calibration curve $\left(\mathrm{r}^{2}\right)$ was $>0.99$. The concentrations of BHT-CHO in the third extraction of

16830 randomly selected dust samples were $<1 \%$ of the values found in the first three

169 extractions while others are undetectable, which indicated that the extraction cycles used in

170 this study completely extracted the target chemicals. For ease of discussion and exposure

171 assessment, dust from homes and other microenvironments were segregated.

172 Statistical Analysis. Statistical analyses were performed with Origin ver. 8 (for profile

173 analyses) and SPSS 16.0 software (for correlation analyses, test for normality and ANOVA).

174 Normality of the data was checked by Shapiro-Wilk test. The 95\% upper confidence limit

175 (UCL) was calculated using ProUCL 4.0. Differences between groups were compared using 
176

177

178

179

180

181

182

183

184

185

186

187

188

189

190

191

192

193

194

a one-way ANOVA followed by a Tukey test. Prior to one-way ANOVA, the data were logtransformed to meet the normality assumptions. The probability value of $p \leq 0.05$ was set for statistical significance.

\section{Results and Discussion}

SPAs in House Dust. BHT was found in $99.5 \%$ of house dust samples and the concentrations varied by five orders of magnitude, from $<1.2 \mathrm{ng} / \mathrm{g}$ to $118 \mu \mathrm{g} / \mathrm{g}$ (Table 1 ).

Highest concentrations of BHT were found in house dust collected from Japan (range: 3.19$33.9 \mu \mathrm{g} / \mathrm{g})$ and South Korea $(2.27-118 \mu \mathrm{g} / \mathrm{g})$, which were 2-3 orders of magnitude higher than the concentrations found in countries with the lowest levels, Romania (0.04-1.59 $\mu \mathrm{g} / \mathrm{g})$ and Vietnam (0.09-0.74 $\mu \mathrm{g} / \mathrm{g})$. SPAs are used as preservatives or additives in household products, ${ }^{15,18}$ which can contribute to their occurrence in settled dust. BHT is also widely used in plastic materials as an antioxidant to stabilize the polymer during processing and to protect plastics through their lifespan ${ }^{15}$. High concentrations of BHT found in both house dust (median $1.55 \mu \mathrm{g} / \mathrm{g}$ ) and sewage sludge (median $2.35 \mu \mathrm{g} / \mathrm{g}$ ) from China indicate the widespread usage of this compound in China. ${ }^{19}$

BHA, a endocrine disrupting chemical (EDC) with potential as a tumor promoter, ${ }^{20,21}$ was found only in house dust from China (ranged from 0.01 to $7.44 \mu \mathrm{g} / \mathrm{g}$ for five cities), whereas this compound was not found in house dust from the other eleven countries studied. 
195 Propyl-, octyl- and dodecyl- gallates are often used as antioxidants in cosmetics and food

196 industry (especially in oils and fats to prevent oxidation). ${ }^{22,23}$ In dust samples, distribution

197 pattern for gallates was different from that of other SPAs, indicating the different usage and

198 sources of gallates. OG was only detected in house dust from China ( $<\mathrm{LOQ}-0.04 \mu \mathrm{g} / \mathrm{g}$ ),

199 Korea (<LOQ-0.14), Saudi Arabia (0.09-0.75) and Japan (<LOQ-0.11), whereas PG was

200 only found in China (<LOQ-1.25) and Saudi Arabia (<LOQ-0.11). DG was found in house

201 dust from China (<LOQ-0.32), Korea (0.31-7.56), the U.S. (<LOQ-0.76), Japan $(<$ LOQ-

202 18.2) and Saudi Arabia (0.01-11.9). Gallates were not found in house dust from Greece,

203 Romania, Kuwait, India, Colombia and Vietnam.

204

205

BHT Metabolites in House Dust. BHT metabolites were found in all house dust samples

206 at total concentrations ( $\left.\sum \mathrm{MTs}\right)$ that ranged from 0.01 to $35.1 \mu \mathrm{g} / \mathrm{g}$. The most abundant

207 metabolites of BHT were BHT-CHO, BHT-OH and BHT-Q, with median concentration

208 ranges of 0.01 to $0.41,<\mathrm{LOQ}$ to 0.93 and $<\mathrm{LOQ}$ to $1.86 \mu \mathrm{g} / \mathrm{g}$, respectively, across twelve

209 countries. The detection frequencies of BHT-Q, BHT-OH, BHT-COOH and BHT-CHO

210 ranged from 38 to $100 \%, 91$ to $100 \%, 87$ to $100 \%$, and 75 to $100 \%$, respectively, across

211 twelve countries. In general, BHT-Q, BHT-OH, BHT-CHO, and BHT-COOH collectively

212 accounted for, on average, 9 to $58 \%$ of the sum of concentrations of SPAs and their

213 metabolites ( $\left.\sum \mathrm{SPA}\right)$. BHT-COOH was found at the lowest concentration in dust. Compared 
214 with other countries studied, higher concentrations of BHT-COOH were found in dust 215 samples from China (median: $0.27 \mu \mathrm{g} / \mathrm{g}$ ) and Saudi Arabia (0.13), and BHT-Q was dominant 216 in dust from the U.S. (1.86 $\mu \mathrm{g} / \mathrm{g})$, Japan (0.87), and Korea (0.47). Similar to the distribution 217 of BHT, the highest median concentration of $\sum$ MTs was determined in house dust from the 218 U.S. (3.02 $\mu \mathrm{g} / \mathrm{g})$, Japan $(1.94 \mu \mathrm{g} / \mathrm{g})$, and South Korea $(1.37 \mu \mathrm{g} / \mathrm{g})$. The toxic effects BHT219 metabolites including DNA damage and carcinogenicity have been reported in several 220 studies $24,25,26,27,28$. The widespread occurrence of BHT-metabolites in indoor dust at high 221 concentrations suggests the need for further studies on potential health effects of these 222 metabolites. SPAs in Dust from Various Microenvironments. The concentrations of $\sum$ SPAs in 224 indoor dust from various microenvironments varied widely (Table S5), with the highest $225 \sum$ SPA mean concentrations found in an e-waste workshop $(4670 \mu \mathrm{g} / \mathrm{g})$ in Vietnam. The 226 median concentrations of $\sum$ SPAs in car dust $(3.76 \mu \mathrm{g} / \mathrm{g})$ from Saudi Arabia were similar to 227 those reported for house dust from the same country $(3.93 \mu \mathrm{g} / \mathrm{g})$. Nevertheless, $\sum$ SPA 228 concentrations in house dust from rural homes (range: 0.64-10.9 $\mu \mathrm{g} / \mathrm{g}$ ) in Pakistan were 229 significantly lower than those from urban $(1.58-14.6 \mu \mathrm{g} / \mathrm{g})$ homes, which might be attributed 230 to different lifestyles including the usage of consumer products. The concentrations of BHT 231 in dust from laboratories and offices in South Korea (range: 2.32-73.8, median: 22.9 and $23233.0 \mu \mathrm{g} / \mathrm{g}$, respectively) were significantly $(p<0.05)$ higher than those in homes (median: 
$2338.21 \mu \mathrm{g} / \mathrm{g}$ ). As one of the widely used stabilizers, SPAs are present in plastics at levels of 234 hundreds to a few thousand $\mathrm{mg}$ per $\mathrm{kg}^{29}$ which might explain for the high concentrations 235 found in numerous microenvironments, such as car, office, and e-waste workshop. Similarly, 236 significantly $(p<0.05)$ higher BHT-metabolite concentrations were found in dust from 237 offices $(2.70-29.9 \mu \mathrm{g} / \mathrm{g})$ and laboratories $(3.60-25.1 \mu \mathrm{g} / \mathrm{g})$ than in homes $(0.51-5.86 \mu \mathrm{g} / \mathrm{g})$ in 238 South Korea. However, higher concentrations of gallates were found in homes (0.31-7.58 $239 \mu \mathrm{g} / \mathrm{g})$ than in laboratories $(0.23-2.48 \mu \mathrm{g} / \mathrm{g})$ and offices $(0.04-5.79 \mu \mathrm{g} / \mathrm{g})$. These differences in 240 the profiles of SPAs suggest that gallates might be primarily used in household products. The 241 use of SPAs in petroleum products and plastics such as electronic equipment and cables, that 242 are widely found in offices/laboratories, is a possible source of their occurrence in these 243 microenvironments. However, dust samples from Pakistan did not show a significant 244 difference in SPA concentrations between offices and homes. The nature and magnitude of 245 indoor products (such as computer, furniture, personal care products, food packages, interior 246 decorations and building material) and ventilation can possibly contribute to variations in 247 SPA profiles in different microenvironments. The highest BHT, gallate and $\sum$ SPA 248 concentrations were found in dust from an e-waste workshop in Vietnam, in the 249 concentration ranges of $425-3460,0.02-684$, and $429-4670 \mu \mathrm{g} / \mathrm{g}$, respectively; these 250 values were four orders of magnitude $(p<0.05)$ higher than those found in dust from homes 251 and offices in Vietnam. The use of BHT in plastic components of e-waste might explain the 
252 high concentrations found in dust from e-waste workshop ${ }^{4}$. The high contamination of SPAs 253 in e-waste workshop found in this study suggests the need for further investigations on 254 occupational exposures in e-waste workshops.

255 SPAs and Their Metabolite Profiles. A significant correlation was found between BHT 256 and $\sum$ MTs in house dust samples from China $(p<0.05)$ and Colombia $(p<0.05)$, which 257 indicated that the dominant source of BHT-metabolites is degradation of BHT itself; 258 however, no significant relationship was found between BHT and $\sum$ MTs in dust from other 259 countries, possibly due to the existence of other sources and transformation pathways. For 260 all the 224 house dust samples, significant correlations $(p<0.05)$ were found among BHT 261 metabolites (Table S6), including BHT-Q, BHT-OH and BHT-COOH, except for BHT262 CHO. The contribution of each of the target compounds to the sum concentrations of $263 \sum$ SPAs analyzed in dust is presented in Figure 1. BHT accounted for up to $89 \%$ of $\sum$ SPA 264 concentrations in dust from Vietnam, followed by Japan $(76 \%)>$ Greece $(73 \%)>$ Korea $265(72 \%)>$ Saudi Arabia $(71 \%)>$ India $(67 \%)>$ the U.S. $(60 \%)>$ Kuwait $(57 \%)>$ Romania $266(53 \%)>$ Pakistan $(50 \%)>$ China $(49 \%)>$ Colombia $(42 \%)$. $\sum$ MTs accounted for 58\% of 267 the total concentrations in dust from Colombia, followed by Pakistan $(50 \%)>$ Romania $268(47 \%)>$ Kuwait $(43 \%)>$ the U.S. $(37 \%)>$ India $(33 \%)>$ China $(30)>$ Greece $(27 \%)>$ 269 Saudi Arabia (17\%) > Japan (12\%) > Vietnam (11\%) > Korea (9\%). The highest 
contributions of BHT-Q, BHT-OH, BHT-CHO and BHT-COOH to $\sum$ MTs were found in

dust from the U.S. (70\%), Pakistan (47\%), India (78\%), and China (28\%), respectively.

272

The proportion of BHT was significantly elevated in dust from an e-waste workshop in

273 Vietnam, which suggested that electronic products are an important source for this chemical.

274 Different profiles were found for the contribution of BHT in dust samples from offices,

275 laboratories, and homes in Korea, with the lowest contribution of $\sum$ MTs found in offices,

276 which suggested different emission sources between homes and the workplace

277 microenvironment. A higher proportion of $\sum$ MTs was found in urban than rural homes in

278 Pakistan, with elevated contribution from BHT-Q in urban homes possibly attributed to

279 differences in the transformation processes. Elevated contribution of OG and PG was found

280 in dust from homes than cars in Saudi Arabia. The proportion of DG was significantly

281 higher in house dust than laboratory and office dusts in Korea. OG, PG and DG are mainly

282 used in foodstuffs, cosmetics and personal care products ${ }^{22,23}$.

283 The profiles of four BHT metabolites in house dust showed a geographical difference

284 among the 12 countries studied, which can be attributed to different emission sources and

285 degradation processes in the indoor environments (Figure S1). The highest contribution (70\%

286 of BHT metabolites) of BHT-Q was found in dust from the U.S., whereas BHT-CHO was

287 found elevated in dust from India, Greece, and Colombia and BHT-OH in China, Japan, 
288 Korea and Pakistan. BHT-COOH was the minor contributor of BHT metabolites, which was

289 a secondary degradation product from BHT-CHO.

290 Potential Indoor Sources of SPAs and Metabolite Products. The results of this study

291 suggests that phenolic antioxidants are widespread in indoor house dust, possibly due to

292 their high production volumes and usage in several consumer products and foodstuffs. SPAs

293 are weakly bound to their substrate, and are thus easily leached from products and enter the

294 environment ${ }^{30}$. BHT is relatively less stable in the indoor environment, which results in

295 abiotic degradation to products such as BHT-CHO, BHT-OH and BHT-Q, which are found

296 at high concentrations in dust. However, the variations in metabolite profiles in different

297 indoor environments and countries suggest the influence of various environmental factors,

298 and further studies are needed to understand the mechanism of transformation of BHT.

299 The occurrence of OG (dr: 0-100\%), PG (dr: 0-90\%), and DG (dr: 0-100\%) in dust from

300 several countries indicates potential sources originating from consumer applications such as

301 cosmetics, hair care products, soaps, shampoos, skin lotions, deodorants, adhesives,

302 margarine, peanut butter and lubricants ${ }^{22}$. Among the three gallates, DG was found as the

303 dominant contributor with the highest detection frequency (detected from six countries) and

304 residue concentrations ( $<\mathrm{LOQ}-18.2 \mu \mathrm{g} / \mathrm{g})$, indicating high usage of DG. DG is used as an

305 anti-ageing agent in polymers. ${ }^{31}$ The differences in the distribution of gallates, BHA and

306 BHT in house dust indicate the existence of multiple sources for these compounds. 

ingestion for different age groups. Median and high exposure scenarios were assessed for BHT, $\sum$ MTs and SPAs based on the median and $95^{\text {th }}$ percentile concentrations determined

310 in dust from household and microenvironments (For details, see supporting information 311 section S1.3; S2.1; Table S7-S9; Figure S2, S3). The acceptable dietary intake (ADI) of 312 BHT has been established by European Food Safety Authority (EFSA) in 2012 at 0.25 $313 \mathrm{mg} / \mathrm{kg} / \mathrm{d}^{32}$ Compared with the mean EDI for BHT via dietary exposure for the general 314 population in Korea reported to be $40 \mu \mathrm{g} / \mathrm{kg}$ bw/day and for the U.S. population at 0.39 and $3150.78 \mathrm{mg} / \mathrm{kg} / \mathrm{d}$ for mean and high exposure scenarios reported by the Joint FAO/WHO 316 Expert Committee on Food Additives (JECFA) (2000) ${ }^{4,33}$, the EDIs from house dust were 317 minor (222 ng/kg/d - maximum). However, since no estimation of EDI of BHT metabolites 318 has been carried out yet., this study assessed the EDI for $\sum$ MTs via house dust exposure and 319 the highest EDI was estimated for toddlers from the U.S. with $152 \mathrm{ng} / \mathrm{kg} / \mathrm{d}$. Overall, 320 contribution of dust ingestion to SPA exposure was two to three orders of magnitude lower 321 than that from dietary route and the ADI. Although this is the first study to report occurrence of a chemical that was not originally suspected to be present in indoor dust, our study has several limitations. First, our

324 small sample size available for each microenvironment (e.g, e-waste workshop) limits our 325 ability to draw inference on the sources and transformation pathways of SPAs. However, it 
326 should be noted that the validity of our results are not affected and further studies with larger

327 sample sizes are needed for the characterization of SPAs in microenvironments. The

328 sampling approach was designed to meet the objective of providing accurate measurements

329 for an emerging class of chemical contaminant in indoor dust. Second, although detailed

330 instructions were provided, household dust samples were collected by local participants and

331 volunteers. Variability in the types of vacuums and sweeping tools used can introduce

332 measurement variations and potential contamination. However, we selected specific particle

333 sizes by sieving the samples in the laboratory which is expected to reduce potential variance

334 introduced by sample collection.

335 In summary, ubiquitous occurrence of several SPAs including BHT and its metabolites

336 were found in indoor dust in this study. BHT was the major SPA in indoor dust samples

337 analyzed from 12 countries $(<\mathrm{LOQ}-3460 \mu \mathrm{g} / \mathrm{g})$. The variations in the profiles of SPAs and

338 their metabolites among various countries and different microenvironments indicated

339 multiple sources and transformation pathways for these compounds. The metabolites of

340 BHT were found at elevated concentrations in dust, which suggest the need for further

341 studies on the toxicity and health effects from exposure to BHT metabolites.

\section{Associated Content}

344 Supporting Information 
345 Supporting data for this article includes additional details of methods, discussion on 346 exposure assessment, as well as sampling information (Table S1), chemical and instrument 347 parameters (Table S2, S3), summary statistics for LOQs and recoveries (Table S4), SPAs 348 concentrations in microenvironments (Table S5), correlation analyses (Table S6), exposure 349 analyses parameters (Table S7), and compound specific exposure estimates (Table S8, S9).

350 Profile plot for BHT metabolites and EDI estimates for compound specific exposure are 351 contained therein.

\section{Author Information}

354 Corresponding Author

355 Tel.: +1 518474 0015; fax: +1 518-473- 2895;

356 E-mail address: Kurunthachalam.kannan@health.ny.gov (K. Kannan).

$357 \quad$ Notes

358 The authors declare no competing financial interests.

\section{Acknowledgments}

361 Pierina Maza-Anaya, a youth research follow, supported by Colciencias, helped in the 362 collection of dust samples from Colombia; Dr. Dilip Kumar Kedia, Patna University, helped 363 in the collection of dust samples from India. This study was funded by a grant 
364 (1U38EH000464-01) from the Centers for Disease Control and Prevention (CDC, Atlanta,

365 GA) to Wadsworth Center, New York State Department of Health. Its contents are solely

366 the responsibility of the authors and do not necessarily represent the official views of the

367 CDC.

368

369

370

\section{References}

371

372

(1) Rodil, R.; Quintana, J. B.; Cela, R. Oxidation of synthetic phenolic antioxidants during

373

374

375

376

377

378

379

380 water chlorination. J. Hazard. Mater. 2012, 199-200 (0), 73-81.

(2) Food and Drug Administration, Code of Federal Regulations, Title 21: Food and Drugs, Office of the Federal Register, Washington, DC, 2001 (Chapter I).

(3) Council Directive 95/2/EC of 20 February 1995 on Food Additives Other than Colours and Sweeteners, OJ L 61, 18.3.1995, Brussels, 1995, p. 1.

(4) Nieva-Echevarria, B.; Manzanos, M.J.; Goicoechea, E.; Guillen, M.D. 2,6-di-tert-butylhydroxytoluene and its metabolites in foods. Compr. Rev. Food Sci. F. 2015, 14 (1), 67-80.

381

382

383

384

385

386

387

388

389

(5) Grice, H.C. Safety evaluation of butylated hydroxyanisole from the perspective of effects on forestomach and esophageal squamous epithelium, Food Chem. Toxicol. 1988, 26 (8), 717-723.

(6) Witschi, H.P. Enhanced tumor-development by butylated hydroxytoluene (BHT) in the liver, lung andgastrointestinal-tract, Food Chem. Toxicol. 1986, 24 (10-11), 11271130.

(7) Botterweck, A.A.M.; Verhagen, H.; Goldbohm, R.A.; Kleinjans, J.; van den Brandt, 390 P.A. Intake of butylated hydroxyanisole and butylated hydroxytoluene and stomach cancer risk: results from analyses in the Netherlands cohort study, Food Chem. Toxicol. 2000, 38 (7), 599-605. 
391 (8) Whysner, J.; Williams, G.M. Butylated hydroxyanisole mechanistic data and risk

392

393

394

395

396

397

398

399

400

401

402

403

404

405

406

407

408

409

410

411

412

413

414

415

416

417

418

419

420

421

422

assessment: conditional species-specific cytotoxicity, enhanced cell proliferation, and tumor promotion, Pharmacol. Ther. 1996, 71 (1-2), 137-151.

(9) Oikawa, S.; Nishino, K.; Oikawa, S.; Inoue, S.; Mizutani, T.; Kawanishi, S. Oxidative DNA damage and apoptosis induced by metabolites of butylated hydroxytoluene. Biochem. Pharmacol. 1998, 56 (3), 361-370.

(10) Matsuo, M.; Mihara, K.; Okuno, M.; Ohkawa, H.; Miyamoto, J. Comparative metabolism of 3,5-di-tert-butyl-4-hydroxytoluene (BHT) in mice and rats. Food Chem. Toxicol. 1984, 22 (5), 345-354.

(11) Fernández-Álvarez, M.; Lores, M.; Jover, E.; García-Jares, C.; Bayona, J.M.; Llompart, M. Photo-solid-phase microextraction of selected indoor air pollutants from office buildings. Identification of their photolysis intermediates, J. Chromatogr. A 2009, 1216 (51), 8969-8978.

(12) Fries, E.; Püttmann, W. Monitoring of the antioxidant BHT and its metabolite BHT$\mathrm{CHO}$ in German river water and ground water. Sci. Total Environ. 2004, 319 (1-3), 269-282.

(13) Rodil, R.; Quintana, J.B.; Basaglia, G.; Pietrogrande, M.C., Cela, R. Determination of synthetic phenolic antioxidants and their metabolites in water samples by downscaled solid-phase extraction, silylation and gas chromatography-mass spectrometry. J. Chromatogr. A, 2010, 1217 (41), 6428-6435.

(14) Eriksson, E.; Baun, A.; Ledin, A. Environmental risk assessment of xenobiotic organic compounds in grey wastewater (Denmark). In: Potential and Problems Related to Reuse of Water in Households. Environment \& Resources, Technical University of Denmark 2002. (Ph.D. Thesis)

(15) Eriksson, E.; Auffarth, K.; Eilersen, A.M.; Henze, M.; Ledin, A. Household chemicals and personal care products as sources for xenobiotic organic compounds in grey wastewater. Water SA 2003, 29 (2) 135.

(16) Guo, Y.; Kannan, K. Comparative Assessment of Human Exposure to Phthalate Esters from House Dust in China and the United States Environ. Sci. Technol., 2011, 45 (8), 3788-3794.

(17) Wang, W.; Huang, M.J.; Chan, C.Y.; Cheung, K.C.; Wong, M.H. Risk assessment of non-dietary exposure to polycyclic aromatic hydrocarbons (PAHs) via PM2.5, TSP 
423

424

425

426

427

428

429

430

431

432

433

434

435

436

437

438

439

440

441

442

443

444

445

446

447

448

449

450

451

452

453

454

and dust in home and the implications from human hair. Atmos. Environ. 2013, 73 (0), 204-213.

(18) HSDB. Hazardous Substances Data Bank. U.S. National Library of Medicine's Toxicology Data Network (TOXNET®), 2002; http:// www.toxnet.nlm.nih.gov/.

(19) Liu, R .; Song, S .; Lin, Y .; Ruan, T .; Jiang, G. Occurrence of synthetic phenolic antioxidants and major metabolites in municipal sewage sludge in China. Environ. Sci. Technol. 2015, 49 (4), 2073-2080.

(20) Chu, W.; Lau, T.K. Ozonation of endocrine disrupting chemical BHA under the suppression effect by salt additive-With and without $\mathrm{H}_{2} \mathrm{O}_{2}$. J. Hazard. Mater. 2007, 144 (1-2), 249-254.

(21) Verhagen, H.; Schilderman, P.A.E.L.; Kleinjans, J.C.S. Butylated hydroxyanisole in perspective. Chemico-Biol. Interact. 1991, 80 (2) 109-134.

(22) Sharla, R. The truth about BHA, BHT, T BHT-Q and other antioxidants used as food additives. Tigmor Books 2009.

(23) Fujita, K.; Kubo, I. Antifungal acitivity of octyl gallate. Int. J. Food Microbiol. 2002, 79 (8), 193-201.

(24) Nagai, F .; Ushiyama, K .; Kano, I. DNA cleavage by metabolites of butylated hydroxytoluene. Arch. Toxicol. 1993, 67 (8), 552-557.

(25) Oikawa, S .; Nishino, K .; Oikawa, S .; Inoue, S .; Mizutani, T ; Kawanishi, S. Oxidative DNA damage and apoptosis induced by metabolites of butylated hydroxytoluene. Biochem. Pharmacol. 1998, 56 (3), 361-370.

(26) Shearn, C.T .; Fritz, K.S .; Meier, B.W .; Kirichenko, O.V .; Thompson, J.A. Carbonyl reductase inactivation may contribute to mouse lung tumor promotion by electrophilic metabolites of butylated hydroxytoluene: Protein alkylation in Vivo and in Vitro. Chem. Res. Toxicol. 2008, 21 (8), 1631-1641.

(27) Kupfer, R .; Dwyer-Nield, L.D. Malkinson, A.M.; Thompson, J.A. Lung toxicity and tumor promotion by hydroxylated derivatives of 2,6-di-tert-butyl-4-methylphenol (BHT) and 2-tert-butyl-4-methyl-6-iso-propylphenol: correlation with quinone methide reactivity. Chem. Res. Toxicol. 2002, 15 (8), 1106-12.

(28) Chevillard, G.; Nouhi, Z.; Anna, D.; Paquet, M.; Blank, V. Nrf3-deficient mice are not protected against acute lung and adipose tissue damages induced by butylated hydroxytoluene. FEBS Lett. 2010, 584 (5), 923-8. 
455

456

457

458

459

460

461

462

463

464

465

466

467

468

469

470

471

472

473

474

475

476
(29) Vitrac, O.; Challe, B.; Leblanc, J.C.; Feigenbaum, A. Contamination of packaged food by substances migrating from a direct-contact plastic layer: Assessment using a generic quantitative household scale methodology. Food Addit. Contam. 2007, 24 (1) $75-94$.

(30) Bart, J.C.J. Polymer Additive Analytics: Industrial Practice and Case Studies; Firenze University Press: Firenze, Italy, 2006.

(31) Masek, A., Chrzescijanska, E., Zaborski, M., Piotrowska, M. Dodecyl gallate as a proecological antioxidant for food packing materials. C. R. Chim. 2014, 17 (11), 1116112.

(32) EFSA-European Food Safety Authority. Panel on Food Additives and Nutrient Sources added to Food (ANS). Scientific opinion on the re-evaluation of butylated hydroxytoluene BHT (E 321) as a food additive. EFSA 2012, 2588 (3) 1-43; DOI: $10.2903 /$ j.efsa.2012.2588.

(33) JECFA-Joint FAO/WHO Expert Committee on Food Additives. Evaluation of certain food additives (Fifty-first report). WHO-World Health Organization Technical 2000. Report Series, Nr. 891; http://whqlibdoc.who.int/trs/WHO_TRS_891.pdf?ua=1. Accessed 2014 July 02. 

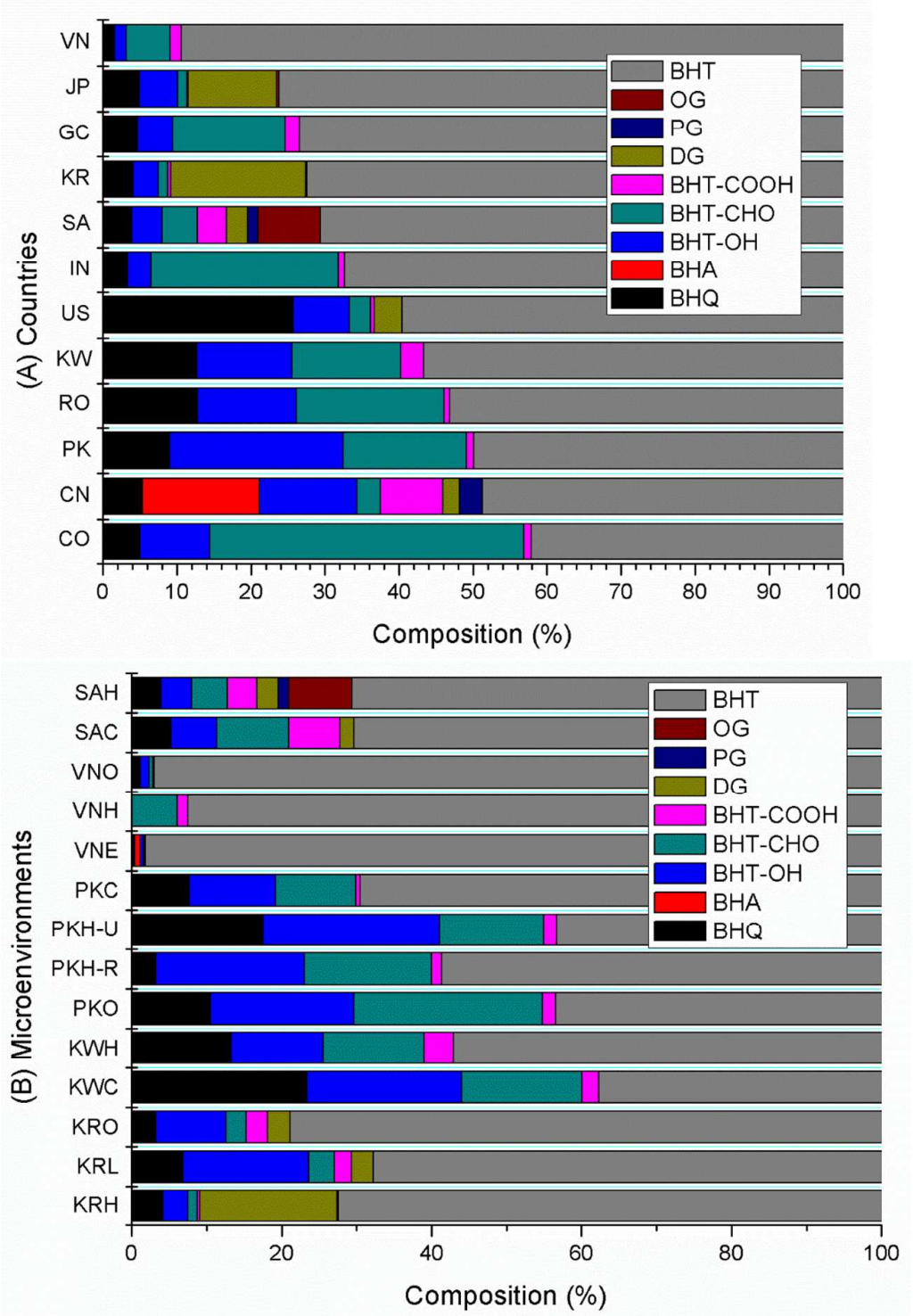

479 Figure 1. Composition profiles of synthetic phenolic antioxidants in house dust from 12 countries (A) 480 and indoor dust from various microenviroments (B) (SAH and SAC-house and car dust from Saudi 481 Arabia; VNO, VNH and VNE-office, house and e-waste workshop dust from Vietnam; PKC, PKH-U, 482 PKH-R, PKO-car, urban house, rural house and office dust from Pakistan; KWH and KWC-house and 483 car dust from Kuwait; KRO, KRL, KRH-office, laboratory, and house dust from South Korea). 
Table 1. Concentrations of synthetic phenolic antioxidants in house dust ( $\mu \mathrm{g} / \mathrm{g} \mathrm{dr}$ weight) from 12 countries

\begin{tabular}{|c|c|c|c|c|c|c|c|c|c|c|c|c|}
\hline 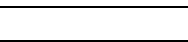 & BHQ & BHA & BHT-OH & BHT-CHO & BHT-COOH & DG & PG & OG & BHT & Gallate $^{b}$ & $\sum S P A s^{c}$ & $\sum \mathrm{MTs}^{\mathrm{d}}$ \\
\hline $\begin{array}{l}\text { Greece }(n=20) \\
\text { median/df } \\
\text { range }\end{array}$ & $\begin{array}{l}0.08 / 100 \\
0.02-0.42\end{array}$ & $\begin{array}{l}<\mathrm{LOQ} / 100 \\
<\mathrm{LOQ}\end{array}$ & $\begin{array}{l}0.09 / 100 \\
0.02-0.38\end{array}$ & $\begin{array}{l}0.27 / 100 \\
0.06-0.86\end{array}$ & $\begin{array}{l}0.03 / 100 \\
0.003-0.18\end{array}$ & $\begin{array}{l}<\mathrm{LOQ} / 0 \\
<\mathrm{LOQ}\end{array}$ & $\begin{array}{l}<\mathrm{LOQ} / 0 \\
<\mathrm{LOQ}\end{array}$ & $\begin{array}{l}<\mathrm{LOQ} / 0 \\
<\mathrm{LOQ}\end{array}$ & $\begin{array}{l}1.33 / 100 \\
0.08-4.56\end{array}$ & $\begin{array}{l}<\mathrm{LOQ} / \\
<\mathrm{LOQ}\end{array}$ & $\begin{array}{l}1.74 / \\
0.84-5.03\end{array}$ & $\begin{array}{l}0.50 / \\
0.16-1.69\end{array}$ \\
\hline $\begin{array}{l}\text { Pakistan }(n=22) \\
\text { median/df } \\
\text { range }\end{array}$ & $\begin{array}{l}0.18 / 95 \\
<\text { LOQ-12.2 }\end{array}$ & $\begin{array}{l}<\mathrm{LOQ} / 0 \\
<\mathrm{LOQ}\end{array}$ & $\begin{array}{l}0.48 / 90.9 \\
<L O Q-1.58\end{array}$ & $\begin{array}{l}0.34 / 100 \\
0.18-1.51\end{array}$ & $\begin{array}{l}0.02 / 95 \\
<L O Q-0.21\end{array}$ & $\begin{array}{l}<\mathrm{LOQ} / 0 \\
<\mathrm{LOQ}\end{array}$ & $\begin{array}{l}<\mathrm{LOQ} / 0 \\
<\mathrm{LOQ}\end{array}$ & $\begin{array}{l}<\mathrm{LOQ} / 0 \\
<\mathrm{LOQ}\end{array}$ & $\begin{array}{l}1.01 / 100 \\
0.29-10.2 \\
\end{array}$ & $\begin{array}{l}<\mathrm{LOQ} / \\
<\mathrm{LOQ}\end{array}$ & $\begin{array}{l}2.87 / \\
0.64-14.6 \\
\end{array}$ & $\begin{array}{l}1.18 / \\
0.23-13.8\end{array}$ \\
\hline $\begin{array}{l}\text { Romania }(n=20) \\
\text { median/df } \\
\text { range }\end{array}$ & $\begin{array}{l}0.13 / 100 \\
0.04-0.31 \\
\end{array}$ & $\begin{array}{l}<\mathrm{LOQ} / 0 \\
<\mathrm{LOQ}\end{array}$ & $\begin{array}{l}0.13 / 100 \\
0.07-0.29 \\
\end{array}$ & $\begin{array}{l}0.20 / 100 \\
0.0-0.62 \\
\end{array}$ & $\begin{array}{l}0.008 / 85 \\
<\text { LOQ-0.10 }\end{array}$ & $\begin{array}{l}<\mathrm{LOQ} / 0 \\
<\mathrm{LOQ}\end{array}$ & $\begin{array}{l}<\mathrm{LOQ} / 0 \\
<\mathrm{LOQ}\end{array}$ & $\begin{array}{l}<\mathrm{LOQ} / 0 \\
<\mathrm{LOQ}\end{array}$ & $\begin{array}{l}0.52 / 100 \\
0.04-1.59 \\
\end{array}$ & $\begin{array}{l}<\mathrm{LOQ} / \\
<\mathrm{LOQ}\end{array}$ & $\begin{array}{l}1.16 / \\
0.39-2.05 \\
\end{array}$ & $\begin{array}{l}0.52 / \\
0.24-0.85 \\
\end{array}$ \\
\hline $\begin{array}{l}\text { China }(n=26) \\
\text { median/df } \\
\text { range }\end{array}$ & $\begin{array}{l}0.17 / 84.6 \\
<\text { LOQ-3.76 }\end{array}$ & $\begin{array}{l}0.50 / 100 \\
0.01-7.44 \\
\end{array}$ & $\begin{array}{l}0.42 / 96.2 \\
<L O Q-4.64\end{array}$ & $\begin{array}{l}0.10 / 87 \\
<L O Q-0.52\end{array}$ & $\begin{array}{l}0.27 / 100 \\
0.004-12.7 \\
\end{array}$ & $\begin{array}{l}0.07 / 62 \\
<\text { LOQ-0.32 }\end{array}$ & $\begin{array}{l}0.10 / 76.9 \\
<L O Q-1.25\end{array}$ & $\begin{array}{l}<\mathrm{LOQ} / 42.3 \\
<\mathrm{LOQ}-0.04\end{array}$ & $\begin{array}{l}1.55 / 96.2 \\
0.13-21.1 \\
\end{array}$ & $\begin{array}{l}0.24 / \\
<L O Q-1.26\end{array}$ & $\begin{array}{l}3.93 / \\
1.04-34.8\end{array}$ & $\begin{array}{l}1.07 / \\
0.49-13.0\end{array}$ \\
\hline $\begin{array}{l}\text { Kuwait }(n=15) \\
\text { median/df } \\
\text { range }\end{array}$ & $\begin{array}{l}0.20 / 86.7 \\
<\text { LOQ-2.48 }\end{array}$ & $\begin{array}{l}<\mathrm{LOQ} / 0 \\
<\mathrm{LOQ}\end{array}$ & $\begin{array}{l}0.21 / 100 \\
0.03-2.33 \\
\end{array}$ & $\begin{array}{l}0.24 / 100 \\
0.11-0.56 \\
\end{array}$ & $\begin{array}{l}0.05 / 100 \\
0.006-0.51 \\
\end{array}$ & $\begin{array}{l}<\mathrm{LOQ} / 0 \\
<\mathrm{LOQ}\end{array}$ & $\begin{array}{l}<\mathrm{LOQ} / 0 \\
<\mathrm{LOQ}\end{array}$ & $\begin{array}{l}<\mathrm{LOQ} / 0 \\
<\mathrm{LOQ}\end{array}$ & $\begin{array}{l}0.91 / 100 \\
0.35-17.4 \\
\end{array}$ & $\begin{array}{l}<\mathrm{LOQ} / 93.3 \\
<\mathrm{LOQ}\end{array}$ & $\begin{array}{l}1.80 / 100 \\
0.79-18.8 \\
\end{array}$ & $\begin{array}{l}0.81 / \\
0.28-5.25\end{array}$ \\
\hline $\begin{array}{l}\text { Korea }(n=26) \\
\text { median/df } \\
\text { range }\end{array}$ & $\begin{array}{l}0.47 / 93.8 \\
<L O Q-2.36\end{array}$ & $\begin{array}{l}<\mathrm{LOQ} / 0 \\
<\mathrm{LOQ}\end{array}$ & $\begin{array}{l}0.38 / 100 \\
0.11-1.73\end{array}$ & $\begin{array}{l}0.14 / 100 \\
0.02-3.02\end{array}$ & $\begin{array}{l}0.05 / 93.8 \\
0.003-1.06\end{array}$ & $\begin{array}{l}2.07 / 100 \\
0.31-7.56\end{array}$ & $\begin{array}{l}<\mathrm{LOQ} / 0 \\
<\mathrm{LOQ}\end{array}$ & $\begin{array}{l}0.018 / 77 \\
<\text { LOQ-0.14 }\end{array}$ & $\begin{array}{l}8.21 / 100 \\
2.27-118 \\
\end{array}$ & $\begin{array}{l}2.11 / 100 \\
0.31-7.58\end{array}$ & $\begin{array}{l}11.5 / \\
3.21-121\end{array}$ & $\begin{array}{l}1.37 / \\
0.51-5.86\end{array}$ \\
\hline $\begin{array}{l}\text { India }(n=30) \\
\text { median/df } \\
\text { range }\end{array}$ & $\begin{array}{l}0.05 / 93 \\
<L O Q-0.36\end{array}$ & $\begin{array}{l}<\mathrm{LOQ} / 0 \\
<\mathrm{LOQ}\end{array}$ & $\begin{array}{l}0.048 / 100 \\
0.01-0.43 \\
\end{array}$ & $\begin{array}{l}0.38 / 100 \\
0.05-0.92 \\
\end{array}$ & $\begin{array}{l}0.01 / 87 \\
<\text { LOQ-0.34 }\end{array}$ & $\begin{array}{l}<\mathrm{LOQ} / 0 \\
<\mathrm{LOQ}\end{array}$ & $\begin{array}{l}<\mathrm{LOQ} / 0 \\
<\mathrm{LOQ}\end{array}$ & $\begin{array}{l}<\mathrm{LOQ} / 0 \\
<\mathrm{LOQ}\end{array}$ & $\begin{array}{l}1.02 / 100 \\
0.05-9.30 \\
\end{array}$ & $\begin{array}{l}<\mathrm{LOQ} / \\
<\mathrm{LOQ}\end{array}$ & $\begin{array}{l}1.62 / \\
0.53-10.6 \\
\end{array}$ & $\begin{array}{l}0.53 / \\
0.06-1.34\end{array}$ \\
\hline $\begin{array}{l}\text { U.S. }(n=14) \\
\text { median/df } \\
\text { range }\end{array}$ & $\begin{array}{l}1.86 / 88.9 \\
<\text { LOQ-8.49 }\end{array}$ & $\begin{array}{l}<\mathrm{LOQ} / 0 \\
<\mathrm{LOQ}\end{array}$ & $\begin{array}{l}0.55 / 88.9 \\
<\text { LOQ-27 }\end{array}$ & $\begin{array}{l}0.21 / 100 \\
0.05-0.74\end{array}$ & $\begin{array}{l}0.04 / 89 \\
<\text { LOQ-0.75 }\end{array}$ & $\begin{array}{l}0.27 / 89 \\
<\text { LOQ-0.76 }\end{array}$ & $\begin{array}{l}<\mathrm{LOQ} / 0 \\
<\mathrm{LOQ}\end{array}$ & $\begin{array}{l}<\mathrm{LOQ} / 0 \\
<\mathrm{LOQ}\end{array}$ & $\begin{array}{l}4.31 / 100 \\
0.76-7.34 \\
\end{array}$ & $\begin{array}{l}0.23 / \\
<\mathrm{LOQ}-0.76\end{array}$ & $\begin{array}{l}8.17 / \\
2.70-39.4 \\
\end{array}$ & $\begin{array}{l}3.02 / \\
0.06-35.1\end{array}$ \\
\hline $\begin{array}{l}\text { Colombia }(n=40) \\
\text { median/df } \\
\text { range }\end{array}$ & $\begin{array}{l}0.049 / 98 \\
<L O Q-2.69\end{array}$ & $\begin{array}{l}<\mathrm{LOQ} / 0 \\
<\mathrm{LOQ}\end{array}$ & $\begin{array}{l}0.09 / 98 \\
<L O Q-0.28\end{array}$ & $\begin{array}{l}0.41 / 100 \\
0.14-1.21 \\
\end{array}$ & $\begin{array}{l}0.01 / 87.5 \\
<\text { LOQ-0.17 }\end{array}$ & $\begin{array}{l}<\mathrm{LOQ} / 0 \\
<\mathrm{LOQ}\end{array}$ & $\begin{array}{l}<\mathrm{LOQ} / 0 \\
<\mathrm{LOQ}\end{array}$ & $\begin{array}{l}<\mathrm{LOQ} / 0 \\
<\mathrm{LOQ}\end{array}$ & $\begin{array}{l}0.41 / 93.9 \\
<\text { LOQ-4.50 }\end{array}$ & $\begin{array}{l}<\mathrm{LOQ} / \\
<\mathrm{LOQ}\end{array}$ & $\begin{array}{l}0.83 / \\
0.17-7.95\end{array}$ & $\begin{array}{l}0.59 / \\
0.17-3.50\end{array}$ \\
\hline $\begin{array}{l}\text { Japan }(n=10) \\
\text { median/df } \\
\text { range }\end{array}$ & $\begin{array}{l}0.88 / 90 \\
0.366-1.461\end{array}$ & $\begin{array}{l}<\mathrm{LOQ} / 0 \\
<\mathrm{LOQ}\end{array}$ & $\begin{array}{l}0.93 / 100 \\
0.03-1.45\end{array}$ & $\begin{array}{l}0.22 / 100 \\
0.006-1.58\end{array}$ & $\begin{array}{l}0.04 / 100 \\
0.001-0.08\end{array}$ & $\begin{array}{l}2.15 / 90 \\
<\text { LOQ-18.2 }\end{array}$ & $\begin{array}{l}<\mathrm{LOQ} / 0 \\
<\mathrm{LOQ}\end{array}$ & $\begin{array}{l}0.05 / 80 \\
<L 0 Q-0.11\end{array}$ & $\begin{array}{l}13.7 / 100 \\
3.19-33.9\end{array}$ & $\begin{array}{l}2.22 / \\
<\text { LOQ-18.2 }\end{array}$ & $\begin{array}{l}20.7 / \\
4.29-43.7\end{array}$ & $\begin{array}{l}1.94 / \\
0.03-3.80\end{array}$ \\
\hline $\begin{array}{l}\text { Saudi Arabia ( } n=1 \\
\text { median/df } \\
\text { range }\end{array}$ & $\begin{array}{l}0.12 / 90 \\
<\text { LOQ-0.39 }\end{array}$ & $\begin{array}{l}<\mathrm{LOQ} / 0 \\
<\mathrm{LOQ}\end{array}$ & $\begin{array}{l}0.13 / 100 \\
0.03-0.37\end{array}$ & $\begin{array}{l}0.15 / 100 \\
0.05-0.33\end{array}$ & $\begin{array}{l}0.13 / 100 \\
0.03-2.66\end{array}$ & $\begin{array}{l}0.09 / 100 \\
0.01-11.9\end{array}$ & $\begin{array}{l}0.04 / 90 \\
<L O Q-0.11\end{array}$ & $\begin{array}{l}0.27 / 100 \\
0.09-0.75\end{array}$ & $\begin{array}{l}2.23 / 100 \\
0.40-6.34 \\
\end{array}$ & $\begin{array}{l}0.41 / \\
0.14-12.2\end{array}$ & $\begin{array}{l}3.93 / \\
1.43-16.3\end{array}$ & $\begin{array}{l}0.58 / \\
0.30-2.79\end{array}$ \\
\hline $\begin{array}{l}\text { Vietnam }(n=8) \\
\text { median/df } \\
\text { range }\end{array}$ & $\begin{array}{l}<\mathrm{LOQ} / 38 \\
<\mathrm{LOQ}-0.02\end{array}$ & $\begin{array}{l}<\mathrm{LOQ} / 0 \\
<\mathrm{LOQ}\end{array}$ & $\begin{array}{l}<\mathrm{LOQ} / 38 \\
<\mathrm{LOQ}-0.02\end{array}$ & $\begin{array}{l}0.01 / 100 \\
0.005-0.08 \\
\end{array}$ & $\begin{array}{l}0.003 / 75 \\
0.002-0.56 \\
\end{array}$ & $\begin{array}{l}<\mathrm{LOQ} / 0 \\
<\mathrm{LOQ}\end{array}$ & $\begin{array}{l}<\mathrm{LOQ} / 0 \\
<\mathrm{LOQ}\end{array}$ & $\begin{array}{l}<\mathrm{LOQ} / 0 \\
<\mathrm{LOQ}\end{array}$ & $\begin{array}{l}0.17 / 100 \\
0.09-0.74 \\
\end{array}$ & $\begin{array}{l}<\mathrm{LOQ} / \\
<\mathrm{LOQ}\end{array}$ & $\begin{array}{l}0.31 / \\
0.15-0.85\end{array}$ & $\begin{array}{l}0.02 / \\
0.01-0.63 \\
\end{array}$ \\
\hline
\end{tabular}


